\title{
GAUSSIAN DECOMPOSITION OF ABSORPTION SPECTRA OF PERIPHERAL LIGHT-HARVESTING COMPLEXES OF PHOTOSYNTHETIC BACTERIA
}

\author{
V. Urbonienė ${ }^{\mathrm{a}}$, O. Vrublevskaja ${ }^{\mathrm{b}}$, G. Trinkūnas $^{\mathrm{b}}$, M. Stakvilevičius $^{\mathrm{c}}$, A. Gall ${ }^{\mathrm{d}}$, \\ B. Robert ${ }^{\mathrm{d}}$, and L. Valkūnas ${ }^{\mathrm{b}, \mathrm{e}}$ \\ ${ }^{a}$ Department of General Physics and Spectroscopy, Vilnius University, Saulètekio 9, LT-10222 Vilnius, Lithuania \\ E-mail: vidita.urbo@gmail.com \\ ${ }^{\mathrm{b}}$ Institute of Physics, Savanoriu 231, LT-02300 Vilnius, Lithuania \\ ${ }^{c}$ Department of Mathematics, Šiauliai University, Višinskio 19, LT-77156 Šiauliai, Lithuania \\ ${ }^{\mathrm{d}}$ Institut de Biologie et Technologie de Saclay, C.E.A. Saclay, 91191 Gif-sur-Yvette Cedex, France \\ e Department of Theoretical Physics, Vilnius University, Saulètekio 9, LT-10222 Vilnius, Lithuania
}

Received 25 January 2007

\begin{abstract}
The absorption spectra of light-harvesting complexes (LH2) purified from Rhodobacter sphaeroides in $60 \%$ glycerol measured in the 4-300 K temperature range have been analysed in terms of linear combination of symmetric Gaussian subbands. All absorption spectra of LH2 are well fitted with sixteen Gaussian subbands. To attribute them to the B800 and B850 bands, the ratio of the integral intensity of those bands is considered, assuming that it should be close to 2 and independent of temperature. From the analysis of the B850 absorption spectrum it is concluded that the maximal value of the resonance interaction between the pigments in the $\mathrm{B} 850$ ring should be 300 and $310 \mathrm{~cm}^{-1}$ at room temperature and $4 \mathrm{~K}$, respectively.

Keywords: absorption spectra, peripheral light-harvesting pigment-protein complex, photosynthetic bacteria, Gaussian
\end{abstract} decomposition

PACS: 71.35.-y, 87.15.-v, 87.15.Aa

\section{Introduction}

The primary processes of photosynthesis occur in membrane pigment-protein complexes. Most of these complexes, called the light-harvesting complexes, absorb the solar energy, convert it into the electronic excitation of pigment molecules, and transfer the excitation to a reaction centre, where the stable charge separation takes place with a subsequent generation of the proton gradient across the photosynthetic membrane $[1,2]$ and ATP synthesis. The description of the high-resolution structural organization of the lightharvesting complexes of purple bacteria of Rhodopseudomonas acidophila (now Rhodoblastus acidophilus) $[3,4]$ has led to significant progress in describing these processes both experimentally and theoretically. In the peripheral antenna complexes of the photosynthetic bacteria, the main pigment molecules - bacteriochlorophylls (BChl) - are organised in highly symmetric circular oligomers [1]. Usually, the exciton concept is applied to describe the absorption properties of these symmetric molecular arrangements [1]. These complexes thus offer a unique opportunity for direct comparison between experimental spectroscopic observations and theoretical predictions.

Light-harvesting antenna complexes of purple photosynthetic bacteria comprise circular aggregates of dimers of transmembrane polypeptides [3,4]. Each of these dimers binds three BChl molecules in the hydrophobic phase of membrane, two of them closely packed together. The strongly coupled BChls are responsible for the absorption of the complex at $850 \mathrm{~nm}$ (the so-called B850 band), while the absorption at $800 \mathrm{~nm}$ (the B800 band) arises from the weakly coupled BChl molecules.

All main spectroscopic features of the absorption spectra in a wide temperature range (from $4 \mathrm{~K}$ to room temperature) and for different conditions of sample preparation can be understood in terms of the exciton model [5-7]. In order to explain these spectroscopic data, the static disorder of pigment site energies, and the coupling of the electronic excitations to intra- and 
intermolecular vibrations/phonons originating in the so-called dynamic disorder have to be taken into account $[1,8]$. According to the linear response theory, which is widely used for the description of the absorption line shape of molecular aggregates, the integral effect of the exciton coupling with molecular vibrations / phonons is defined by the spectral density function (SDF) [9]. The parametric form of the SDF of the BChl molecules can be well determined semiempirically by fitting the series of experimental data of the absorption spectra obtained over a wide temperature range $[5-7,10,11]$. However, values of these parameters interfere with the parameters determining the pure exciton spectrum, i. e., the change of one of them necessitates the changes of the others. This is probably the reason why there is a significant variation in the exciton model parameters determined from different experimental observations. Indeed, the resonance intermolecular interaction between the nearest B850 pigments in the LH2 from Rhodobacter (Rb.) sphaeroides have been reported as equal to $\sim 375-420 \mathrm{~cm}^{-1}$ from the analysis of the temperature dependent fluorescence spectra $[12,13]$, to $\sim 360 \mathrm{~cm}^{-1}$ when defined by estimating the exciton bandwidth [14], to $\sim 320 \mathrm{~cm}^{-1}$ from the analysis of the hole-burning experiments [15], and to $\sim 300 \mathrm{~cm}^{-1}$ from the CD spectra $[16,17]$. Thus, the precise determination of the value of the resonance interaction (as well as the exciton bandwidth) requires further analysis to overcome the uncertainty due to variability of the ensemble of parameters of the system.

Here we propose another approach for determining the exciton bandwidth. This approach is based on calculations of the ratio of the integral dipole strengths for B850 and B800 bands in a wide temperature range. Evidently, this ratio should be close to the ratio of the amount of the pigment molecules and has to be temperature independent. The possible effect of the disorder on the characterisation of the value of the resonance interactions is also discussed.

\section{Materials and methods}

\subsection{Preparation of samples}

The LH2 complexes of $R b$. sphaeroides 2.4 .1 were isolated according to the procedure described in $[5,18]$. For use in the absorption studies, LH2 samples were prepared in $20 \mathrm{mM}$ Tris[hydroxymethyl]aminomethane (Tris. Cl) (pH 8.5) buffer containing $0.1 \%$ LDAO $(\mathrm{N}, \mathrm{N}-$ Dimethyldodecylamine-N-oxide, $\mathrm{w} / \mathrm{v}$ ) and $60 \%$ glycerol concentration. As such glycerol/ buffer solutions

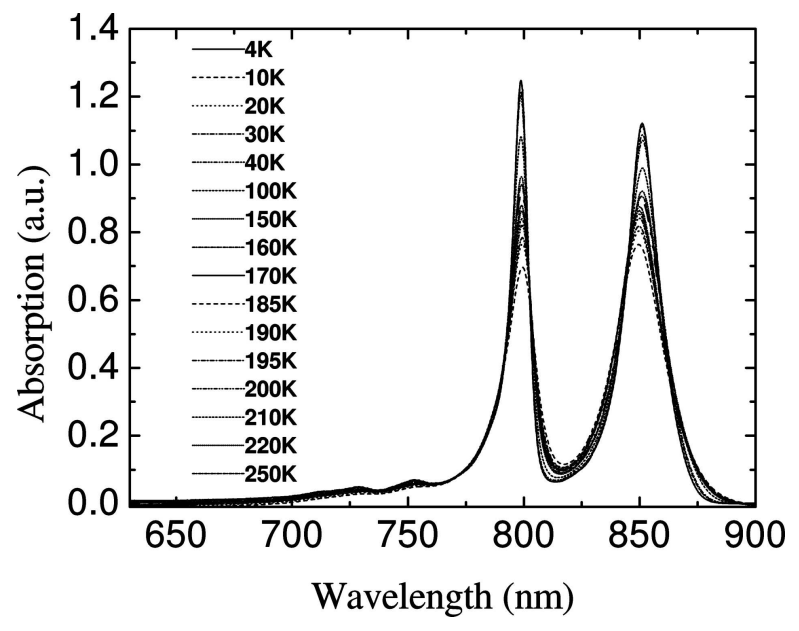

Fig. 1. Absorption spectra of purified LH2 from $R b$. sphaeroides in $60 \%$ buffer / glycerol solution for the 4-250 K temperature range.

exhibit a phase transition around $200 \mathrm{~K}$, the complete temperature cycle could be only measured by progressively decreasing temperature. The 4-200 K range was also achieved by slowly raising the temperature. In order to ensure the equilibrium between the sample and the helium bath, the sample was stabilized at each measured temperature for at least 15 minutes.

\subsection{Spectroscopic analysis}

Electronic absorption spectra were collected using a Varian Cary E5 double beam scanning spectrophotometer. Temperature of the samples was precisely maintained by the Helium bath cryostat (Maico Metriks, Tartu, Estonia).

\subsection{Curve fitting}

The recorded spectra were corrected for the background absorption of the sample. The latter was determined at each temperature by measuring the absorption of the cuvette without a sample, but filled with the Tris. Cl/glycerol solvent. All spectral data were analysed using the Origin 6.0 package. Spectral decomposition was performed using the Mathcad 11 package.

\section{Results}

The absorption spectra of purified LH2 complexes from $R b$. sphaeroides contain the typical two bands, $\mathrm{B} 800$ and $\mathrm{B} 850$, corresponding to the two $\mathrm{BChl}$ rings present in the structure. The temperature dependence of the absorption spectra in the visible and nearinfrared (630-900 $\mathrm{nm}$ ) region obtained in the 4-250 K temperature range is shown in Fig. 1. Both B800 and 
B850 bands become narrower with a slight red shift of the B850 band and a blue shift of the B800 band when decreasing the temperature.

The exciton bandwidth of the $\mathrm{BChl}$ molecules of the B850 ring is quite wide as estimated from the resonance intermolecular interactions. It is actually overlapping with the absorption spectrum of the BChl molecules absorbing at $800 \mathrm{~nm}$. To discriminate between the optical transitions corresponding to B800 and $\mathrm{B} 850$ bands the absorption spectrum should be decomposed into its constituents. Such spectral decomposition of the absorption spectra of the LH2 obtained at $4 \mathrm{~K}$ and $250 \mathrm{~K}$ temperature is shown in Fig. 2. It is worthwhile to mention that the fitting procedure is applied to the spectrum on the frequency scale, while the spectra shown in Fig. 2 are presented on the wavelength scale as usually the experimental data are presented. The spectra at all temperatures can be well fitted with a linear combination of 16 Gaussian bands. A smaller number of Gaussians results in a worse fit of the absorption spectra, while further increase of the number of Gaussians does not contribute to any noticeable improvement. This amount of the components of the spectrum can be related to the combined excitonic and/or vibronic transitions of the pigment molecules from the $\mathrm{B} 800$ and $\mathrm{B} 850$ rings [1].

From such decomposition, it is possible to attribute different transitions to different constituents, i. e., to the B800 and B850 transitions. The long wavelength transitions in the vicinity of $850 \mathrm{~nm}$ should be evidently attributed to the B850 band. However, the transitions in the vicinity of $800 \mathrm{~nm}$ can be related to both B800 and B850 bands, as the high-energy states of the exciton band from the pigment molecules belonging to $\mathrm{B} 850$ ring are expected in the vicinity of $800 \mathrm{~nm}$ [16]. Since the amount of pigment molecules in the B850 ring is twice as much as the amount of pigment molecules in the B800 ring, the ratio of the integral transition dipole strengths of these transitions should be close to 2. Moreover, this ratio should be temperatureindependent. Depending on the attribution of different components to B850 and / or B800, a different temperature dependence of this ratio is observed (Fig. 3 and Table 1). Erroneous attribution of the subbands to the constituents of the spectra induces a temperature dependence of this ratio. As demonstrated in Fig. 3(c), the ratio of the integral dipole strengths $\mathrm{B} 850 / \mathrm{B} 800$ can be obtained almost temperature-independent and close to 2 for one specific attribution of the Gaussian subbands in the vicinity of $800 \mathrm{~nm}$. In this case the components labelled as p1, p2, p3, p4, p5, p6, p11, p12, p14, p15,
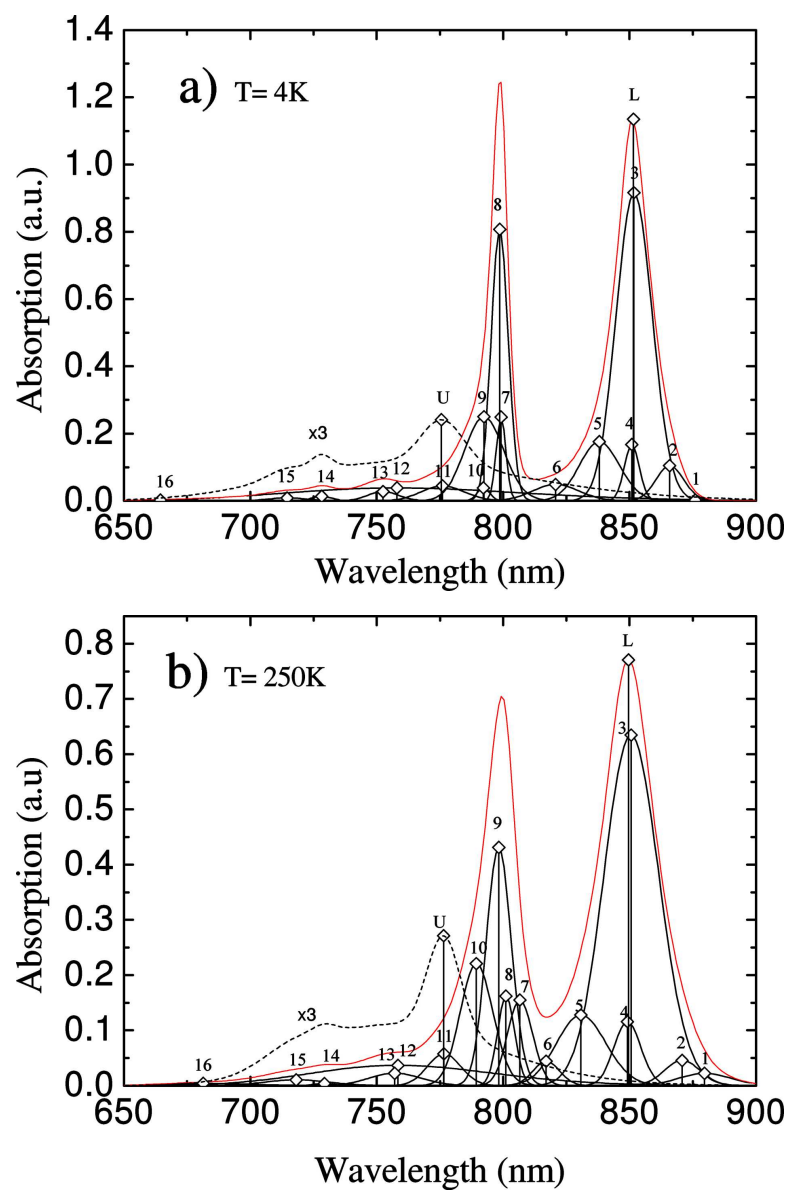

Fig. 2. Absorption spectra of purified LH2 from $R b$. sphaeroides in $60 \%$ buffer/glycerol solution and their spectral decomposition into Gaussain subbands at (a) $4 \mathrm{~K}$, (b) $250 \mathrm{~K}$ temperatures. The bands with maximum labelled $\mathrm{U}$ (the upper excitonic transitions) represent the integral band of the subbands p11, p12, p14, p15, and p16. The amplitude of this integral band is increased three times for better visibility. The maximum of the $\mathrm{B} 850$ is also labelled $\mathrm{L}$ to indicate the strongest transitions of the lower excitonic subband.

p16 are attributed to the $\mathrm{B} 850$ band and the rest of the components are related to the $\mathrm{B} 800$ band.

Parameters of the Gaussians subbands while fitting the absorption spectra were kept as free fitting values. Values obtained for two temperature limits are given in Table 2.

\section{Discussion}

Although the transitions at 800 and $850 \mathrm{~nm}$ mainly correspond to the two different rings of BChls in LH2 complexes, the overlap of the exciton states of the B850 band with the B800 band makes the precise attribution of all the spectral features complicated. To resolve this problem, we analyse the absorption spectra of the LH2 complexes isolated from $R b$. sphaeroides obtained at different temperatures (from 4 to $300 \mathrm{~K}$ ) in 
Table 1. Attribution of the subbands to the B800 and B850 transitions.

\begin{tabular}{cll}
\hline Set of subbands & \multicolumn{1}{c}{ Bands attributed to B850 } & \multicolumn{1}{c}{ Bands attributed to B800 } \\
\hline 1 & Integral area, range 900-815 nm & Integral area, range 815-775 nm \\
2 & $\mathrm{p} 1, \mathrm{p} 2, \mathrm{p} 3, \mathrm{p} 4, \mathrm{p} 5, \mathrm{p} 6, \mathrm{p} 11, \mathrm{p} 12, \mathrm{p} 13, \mathrm{p} 14, \mathrm{p} 15, \mathrm{p} 16$ & $\mathrm{p} 7, \mathrm{p} 8, \mathrm{p} 9, \mathrm{p} 10$ \\
3 & $\mathrm{p} 1, \mathrm{p} 2, \mathrm{p} 3, \mathrm{p} 4, \mathrm{p} 5, \mathrm{p} 6, \mathrm{p} 11, \mathrm{p} 12, \mathrm{p} 14, \mathrm{p} 15, \mathrm{p} 16$ & $\mathrm{p} 7, \mathrm{p} 8, \mathrm{p} 9, \mathrm{p} 10, \mathrm{p} 13$ \\
\hline
\end{tabular}

Table 2. Gaussian subbands obtained from decomposition of the absorption spectra of purified LH2 from $R b$. sphaeroides in $60 \%$ buffer/glycerol solution at the 4 and $250 \mathrm{~K}$ temperature. $\lambda$ indicates the maxima of the subbands, FWHM denotes their full bandwidths at half of maxima, and $S$ defines their area.

\begin{tabular}{|c|c|c|c|c|c|c|c|}
\hline \multirow{2}{*}{\multicolumn{2}{|c|}{$\begin{array}{c}\text { Temperature } \\
\text { Parameters }\end{array}$}} & \multicolumn{3}{|c|}{$4 \mathrm{~K}$} & \multicolumn{3}{|c|}{$250 \mathrm{~K}$} \\
\hline & & $\lambda, \mathrm{nm}$ & FWHM, $\mathrm{cm}^{-1}$ & $S$, rel. u. & $\lambda, \mathrm{nm}$ & FWHM, $\mathrm{cm}^{-1}$ & $S$, rel. u. \\
\hline \multirow{11}{*}{ B850 } & p1 & 876.0 & 41 & 4 & 879.7 & 134 & 142 \\
\hline & p2 & 865.9 & 73 & 361 & 870.7 & 93 & 204 \\
\hline & p3 & 851.8 & 98 & 4241 & 850.5 & 149 & 4527 \\
\hline & $\mathrm{p} 4$ & 850.9 & 41 & 324 & 849.1 & 73 & 407 \\
\hline & p5 & 838.0 & 112 & 931 & 830.8 & 140 & 861 \\
\hline & p6 & 820.7 & 135 & 313 & 817.0 & 79 & 168 \\
\hline & p11 & 776.0 & 140 & 296 & 776.5 & 109 & 302 \\
\hline & p12 & 758.1 & 818 & 1486 & 758.4 & 630 & 1113 \\
\hline & p14 & 728.2 & 75 & 47 & 729.3 & 81 & 15 \\
\hline & p15 & 714.6 & 149 & 62 & 718.2 & 246 & 126 \\
\hline & p16 & 664.4 & 448 & 44 & 681.4 & 390 & 78 \\
\hline \multirow{5}{*}{ B800 } & $\mathrm{p} 7$ & 799.2 & 799 & 358 & 806.6 & 76 & 568 \\
\hline & p8 & 798.6 & 799 & 2026 & 801.1 & 52 & 408 \\
\hline & p9 & 792.4 & 792 & 1451 & 798.2 & 78 & 1604 \\
\hline & p10 & 792.2 & 792 & 73 & 789.4 & 104 & 1097 \\
\hline & p13 & 752.4 & 752 & 138 & 757.1 & 180 & 194 \\
\hline
\end{tabular}

terms of a linear combination of symmetric Gaussian bands. Such deconvolution of the spectra was already applied to the analysis of the weakly coupled chlorophyll molecules in the major photosynthetic complexes of plants $[19,20]$. Here we apply this method to the analysis of the strongly coupled pigments arranging the collective exciton states. Evidently, the amount of the Gaussian subbands for the excitonically coupled system should not be equal to the amount of the absorbing molecules. Therefore, the parameters of the Gaussian subbands as well as their amount were chosen as free fitting parameters of the absorption spectra at different temperatures. The most accurate fit of the spectra is obtained with 16 Gaussian subbands at all temperatures. To get the ratio of the integral dipole strengths of B850 to $\mathrm{B} 800$ bands close to 2 at all temperatures some components on the blue side of the spectrum determined by fitting, namely, p11, p12, p14, p15, p16, have to be attributed to the B850 exciton band. Any different attribution of the subbands on the blue side of the spectrum demonstrates strong temperature dependence of the integral transition ratio (see Fig. 3 and Table 1). Summing them up (see the bands labelled U in Fig. 2) the band shape and the maximum of the blue edge of the absorption corresponding to the B850 exciton band can be defined.

The exciton spectrum of the molecular aggregate must obey the ring symmetry with the transition dipole moment of the molecule oriented predominantly in the plane of the ring. The strongest transition then corresponds to the two states $(k= \pm 1)$ next to the lowest exciton state [1]. For the aggregates with two molecules per unit cell the same feature is also characteristic of the states next to the highest excitonic state $(k= \pm 8$ in the case of the aggregate containing 9 dimers). However, the transition intensities of the latter states are weaker by two orders of magnitude. Evidently, any type of disorder partially destroys the selection rules and the degeneracy of the states corresponding to the ideal ring symmetry. As a result, the dipole strengths of the transitions into all exciton states are redistributed with gain in dipole strengths for weak and even forbidden exciton states. According to the structural data, BChls in the B850 ring are organized in a ring of dimers with the ratio of the resonance interaction within the dimer and between the dimers of 1.32 [4]. Thus, by taking into account this ratio and attributing the maxima of the optical transitions (U for upper and L for lower, see 
Fig. 3) to $k= \pm 8$ and $k= \pm 1$ states of the $\mathrm{B} 850$ exciton band, the energy gap between these transitions should correspond to $3.7 \mathrm{~V}$, where $V$ is the value of the resonance interaction within the dimer. According to these estimations the latter should give $V=310$ and $300 \mathrm{~cm}^{-1}$ for 4 and $250 \mathrm{~K}$, respectively. Such estimation is related to the ideal ring-type arrangement of the molecules in the aggregate. However, this phenomenon statistically persists for the ensemble of the randomly disordered ring-type aggregates with the additional input of the value of disorder. Thus, the given estimations should be considered as upper limits for the resonance interaction.

The obtained values of the resonance interaction are close to the lowest resonance interactions determined by other semiempirical approaches (see Introduction). The slight temperature dependence of the resonance interaction determined by our estimations most probably reflects the temperature dependence of the dielectric constant of the solvent as has already been outlined recently [7]. According to the subband attribution the absorption above the U-maximum (see Fig. 2) should be related to the vibronic transitions accompanying the excitonic transitions of the $\mathrm{B} 850$ band.

\section{Acknowledgements}

This research was supported by the Lithuanian State Science and Studies Foundation and by a Gilibert project in support of French-Lithuanian scientific collaboration. V. U. also acknowledges the Marie Curie Host fellowship Programme, contract No. HPMT-CT2000-00162.

\section{References}

[1] H. van Amerongen, L. Valkunas, and R. van Grondelle, Photosynthetic Excitons (World Scientific, Singapore, 2000).

[2] R.E. Blankenship, Molecular Mechanisms of Photosynthesis (Blackwell Science, Oxford, 2002).

[3] G. McDermott, S.M. Prince, A.A. Freer, A.M. Hawthornthwaite-Lawless, M.Z. Papiz, R.J. Cogdell, and N.W. Isaacs, Crystal structure of an integral membrane light-harvesting complex from photosynthetic bacteria, Nature 374, 517-521 (1995).

[4] M.Z. Papiz, S.M. Prince, T. Howard, R.J. Cogdell, and N.W. Isaacs, The structure and thermal motion of the the B800-850 LH2 complex from Rps. acidophila at $2.0 \AA$ resolution and $100 \mathrm{~K}$ : New structural features and functionally relevant motions, J. Mol. Biol. 326(5), 1523-1538 (2003).
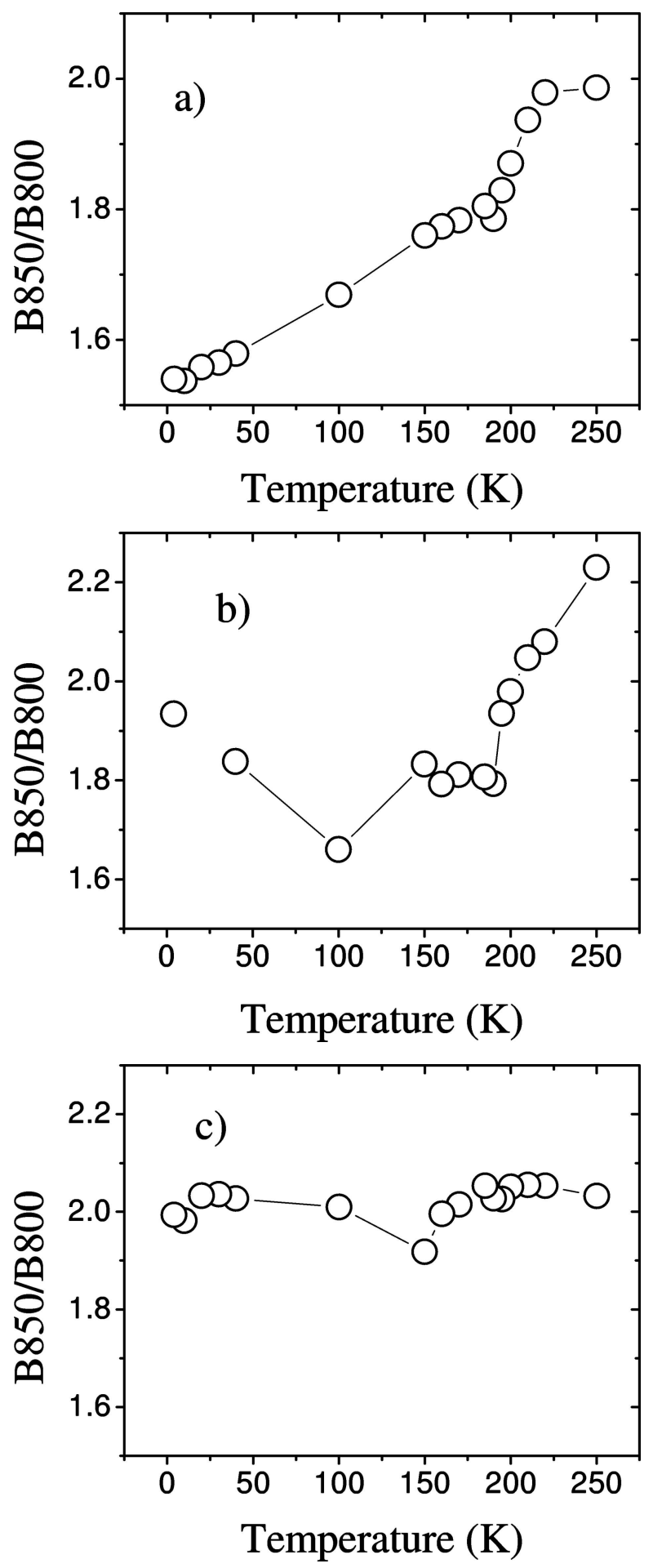

Fig. 3. Temperature dependences of ratio of B850/B800 areas: (a) corresponds to set 1 of subbands, (b) to set 2, and (c) to set 3 given in Table 1.

[5] V. Urboniene, O. Vrublevskaja, A. Gall, G. Trinkunas, B. Robert, and L. Valkunas, Temperature broadening of LH2 absorption in glycerol solution, Photosynthesis Res. 86(1-2), 49-59 (2005).

[6] O. Vrublevskaja, V. Urbonienè, G. Trinkūnas, L. Valkūnas, A. Gall, and B. Robert, Estimation of 
the spectral density function of LH2 complexes from the temperature dependence of the absorption spectra, Lithuanian J. Phys. 46(1), 39-46 (2006).

[7] V. Urboniene, O. Vrublevskaja, G. Trinkunas, A. Gall, B. Robert, and L. Valkunas, Solvation efect of bacteriochlorophyll excitons in light-harvesting complexes LH2, Biophys. J. (2007, in press).

[8] R. van Grondelle and V.I. Novoderezhkin, Energy transfer in photosynthesis: Experimental insights and quantitative models, Phys. Chem. Chem. Phys. 8(7), 793-807 (2006).

[9] S. Mukamel, Principles of Nonlinear Optical Spectroscopy (Oxford, New York, 1995).

[10] T. Renger and R.A. Marcus, On the relation of protein dynamics and exciton relaxation in pigment-protein complexes: An estimation of the spectral density and a theory for the calculation of optical spectra, J. Chem. Phys. 116(22), 9997-10019 (2002).

[11] S. Jang and R.J. Silbey, Single complex line shapes of the B850 band of LH2, J. Chem. Phys., 118(20), 93249336 (2003).

[12] A. Freiberg, M. Rätsep, K. Timpmann, G. Trinkunas, and N.W. Woodbury, Self-trapped excitons in LH2 antenna complexes between $5 \mathrm{~K}$ and ambient temperature, J. Phys. Chem. B 107(41), 11510-11519 (2003).

[13] A. Freiberg, K. Timpmann, R. Ruus, and N.W. Woodbury, Disordered exciton analysis of linear and nonlinear absorption spectra of antenna bacteriochlorophyll aggregates: LH2-only mutant chromatophores of Rhodobacter sphaeroides at $8 \mathrm{~K}$ under spectrally selective excitation, J. Phys. Chem. B 103(45), 1003210041 (1999).

[14] K. Timpmann, G. Trinkunas, J.D. Olsen, C.N. Hunter, and A. Freiberg, Bandwidth of excitons in bacterial antenna chromoproteins. Chem. Phys. Lett. 398(4-6), 384-388 (2004).

[15] H.M. Wu, N.R.S. Reddy, and G.J. Small, Direct observation and hole burning of the lowest exciton level (B870) of the LH2 antenna complex of Rhodopseudomonas acidophila (strain 10050), J. Phys. Chem., B 101(4), 651-656 (1997).

[16] M.H.C. Koolhaas, R.N. Frese, G.J.S. Fowler, T.S. Bibby, S. Georgakopoulou, G. van der Zwan, C.N. Hunter, and R. van Grondelle, Identification of the upper exciton component of the B850 bacteriochlorophylls of the LH2 antenna complex, using a B800-free mutant of Rhodobacter sphaeroides, Biochem. 37(14), 4693-4698 (1998).

[17] S. Georgakopoulou, R.N. Fresse, E. Johnson, C. Koolhaas, R.J. Cogdell, R. van Grondelle, and G. van der Zwan, Absorption and CD spectroscopy and modeling of various LH2 complexes from purple bacteria, Biophys. J. 82(4), 2184-2197 (2002).

[18] A. Gall and B. Robert, Characterization of the different peripheral light-harvesting complexes from high- and low-light grown cells from Rhodopseudomonas palustris, Biochem.38(6), 5185-5190 (1999).

[19] R.C. Jennings, R. Bassi, F.M. Garlaxhi, P. Dainese, and G. Zucchelli, Distribution of the chlorophyll spectral forms in the chlorophyll-protein complexes of photosystem II antenna, Biochem. 32(13), 3203-3210 (1993).

[20] G. Trinkunas, J.P. Connelly, M.G. Mü1ller, L. Valkunas, and A.R. Holzwarth, Model for the excitation dynamics in the light-harvesting complex II from higher plants, J. Phys. Chem. B 101(37), 7313-7320 (1997).

\title{
FOTOSINTETINANČIŲ BAKTERIJŲ PERIFERINIŲ ŠVIESĄ SURENKANČIŲ KOMPLEKSU SUGERTIES SPEKTRU SKAIDYMAS GAUSO SANDAIS
}

\author{
V. Urbonienė ${ }^{\mathrm{a}}$, O. Vrublevskaja ${ }^{\mathrm{b}}$, G. Trinkūnas ${ }^{\mathrm{b}}$, M. Stakvilevičius ${ }^{\mathrm{c}}$, A. Gall $^{\mathrm{d}}$, B. Robert ${ }^{\mathrm{d}}$, L. Valkūnas ${ }^{\mathrm{b}, \mathrm{a}}$ \\ ${ }^{a}$ Vilniaus universitetas, Vilnius, Lietuva \\ ${ }^{\mathrm{b}}$ Fizikos institutas, Vilnius, Lietuva \\ c Šiauliu universitetas, Šiauliai, Lietuva \\ ${ }^{\mathrm{d}}$ C.E.A. Saclay, Prancūzija
}

\section{Santrauka}

Periferinių šviesą surenkančių kompleksų LH2, išskirtų iš Rhodobacter sphaeroides fotosintetinančiu bakterijų, esančių $60 \%$ Tris[hidrometil]aminometano (Tris. Cl) / glicerolio buferyje, sugerties spektrų kontūrai išskaidyti Gauso sandais. Visi sugerties spektrai buvo aproksimuoti šešiolikos Gauso sandų sumos funkcija. Gauso sandai buvo priskirti B800 ir B850 sugerties juostoms, pa- darius prielaidą, kad šiu juostų integralinio intensyvumo santykis turi būti maždaug 2 ir nepriklausyti nuo temperatūros.

Gauso sandai, priskirti B850 sugerties juostoms, leido ìvertinti tankiau išdèstytų bakteriochlorofilo pigmentų rezonansinę sąveiką, kurios dydis $300 \mathrm{~cm}^{-1}$ kambario temperatūroje ir $310 \mathrm{~cm}^{-1} 4 \mathrm{~K}$ temperatūroje. Šią nežymią rezonansinès sąveikos priklausomybę nuo temperatūros galima aiškinti tirpiklio dielektrinès konstantos priklausomybe nuo temperatūros. 